\title{
Stapafurdius, a new genus of Bulimulidae (Mollusca, Eupulmonata) from Bahia, Brazil, with two new species
}

\author{
Luiz Ricardo L. Simone' \\ 1 Universidade de São Paulo (USP), Museu de Zoologia (MZUSP). São Paulo, SP, Brasil. \\ ORCID: http://orcid.org/0000-0002-1397-9823. E-mail: Irsimone@usp.br
}

\begin{abstract}
The new genus Stapafurdius gen. nov. is introduced collected from Bahia, Brazil, including two new species: S. glaber sp. nov., the type species, occurs in Ibicoara; and S. costiferus sp. nov., from Andaraí regions. The new genus includes species of about $10 \mathrm{~mm}$, elongated shell, reticulated protoconch, elongated peristome, and wide umbilicus. Both species differ mainly by the sculpture, as S. glaber sp. nov. is smooth, while $S$. costiferus sp. nov. has strong axial sculpture. http://zoobank.org/C851695E-6BF1-4418-8D8A-8BC7D10CC2FE.
\end{abstract}

Keywords. Taxonomy; Faunistic survey; Morphology; Malacology.

\section{INTRODUCTION}

Recent expedition of the collection team of the naturalist José Coltro in calcareous regions from Minas Gerais and Northeast Brazil has brought to light a quantity of new samples, promoting expansions on the geographic distribution of know species, as well as several new taxa (e.g., Simone, in press). This operation is presently facilitated by complete inventories of the Brazilian continental malacofauna (Simone, 2006; Birckolz et al., 2016), in which new taxa can easily be detected.

The present paper refers to samples collected in the central Bahia region, in a semi-dry environment, for which the analysis revealed to belong to a new genus, formally described herein. Two new species are easily detected, one from the Andaraí, and the other from the Ibicoara municipalities.

As the samples are composed only of shells, no information on the internal anatomy is so far possible. However, the shells are informative enough to base the taxonomical analysis. Some doubt, however, remains in the family attribution, an issue stressed in the Discussion section.

\section{MATERIAL AND METHODS}

The samples were donated dry and deposited in the malacological collection of the Museu de Zoologia da Universidade de São Paulo (MZSP). The specimens were carefully examined under stereomicroscopes and digitally photographed by Nikon and Canon cameras, as well as by AxioCam ERc5s coupled in the microscope. All images were processed in the Corel software, mainly PhotoPaint ${ }^{\circledR}$, and by AxioVision multifocal software. A pair of young specimens were selected for Scanning Electron Microscopy; they were covered by gold and examined by ordinary methods, with main concern to the protoconch sculpture. The list of material examined is the type material mentioned in each species description. Most of the generic definition used in the Discussion was based on Pilsbry (1897-1898), beyond the indicated references.

\section{RESULTS}

\section{Systematics}

\section{Stapafurdius, new genus} http://zoobank.org/62317493-2B7C-47F5-B55B-3EAA45EA79E4

Diagnosis: Shell of $\sim 10 \mathrm{~mm}$, relatively elongated, length $\sim 3$ times width. Color beige with irregular brown spots. Suture well marked. Protoconch mostly sculptured by with delicate net of spiral and axial lines forming aligned squared concave pits, $~ 2.5$ whorls. Teleoconch $\sim$ 4-5 whorls. Peristome weakly dislocated externally, weakly deflected, antero-posteriorly elongated ( twice longer than wide). Umbilicus opened, flanked by middle region of inner lip.

Gender: Masculine. 
Etymology: The name is the Latinization of the Portuguese word "estapafúrdio", meaning something weird, strange or nonsense, an allusion to the strange shape of the shell.

List of included taxa: Stapafurdius glaber sp. nov. (type species); S. costiferus sp. nov.

\section{Stapafurdius glaber sp. nov.}

(Figs. 1-12, 24-26)

\section{http://zoobank.org/B21ABE18-E5FE-4B08-AC63-FA4B51085F64}

Types: Holotype MZSP 154048 (Figs. 1-6). Paratypes MZSP 153803, 5 shells, MZSP 154047, 9 shells (Figs. 7-8, 11-12), from type locality.

Type locality: BRAZIL. Bahia: Ibicoara; Ituaçu, Tanhaçu, $13^{\circ} 55^{\prime} 23^{\prime \prime} \mathrm{S}, 41^{\circ} 16^{\prime} 35^{\prime \prime} \mathrm{W}$ [Wesley Vailant col., iii/2021] (Fig. 30).

Etymology:The specific epithet is from Latin glaber, meaning smooth, an allusion to the lack of the shell sculpture.

Diagnosis: Shell rather conic, sculpture missing except for growth lines.

\section{Description}

Shell: About $10 \mathrm{~mm}$, elongated, slightly turriform; width $\sim 36 \%$ of length. Spire angle $\sim 30^{\circ}$, growth increasing relatively uniformly, except for peristome slightly dislocated externally. Color pale beige, with small, punctiform brown spot, of apparent random distribution, coalescent in some regions forming irregular axial bands (Figs. 1, 3, 7, 11). Protoconch (Figs. 5, 12, 25, 26) of 2.2 whorls, width $1.2 \mathrm{~mm}$; whorls relatively rounded, suture deep; sculpture delicate net of spiral and axial lines, equally predominating, uniform, easily eroded (Fig. 5); $\sim 45 \%$ of shell width, $\sim 8 \%$ of shell length; transition with teleoconch relatively clear, prosocline, $\sim 20^{\circ}$ in relation of longitudinal axis (Figs. 25, 26). Teleoconch of $\sim 4$ whorls, suture relatively shallow, but well-marked; transverse section rounded (Fig. 6); growth relatively uniform, except for peristome, slightly dislocated externally to right. Sculpture missing, except for growth lines and scanty axial undulations (Fig. 26); surface relatively glossy, small regions of dark spots with weak depression (Figs. 3, 8, 10). Aperture antero-posteriorly elongated, width 40\% of length (Figs. 1, 7, 9); peristome slightly prosocline, $\sim 10 \%$ in relation to longitudinal axis (Figs. 2, 4); outer lip straight in middle, curved in both ends; anterior edge rounded; inner lip relatively similar to outer lip, attached to last whorl only in its superior third, sometimes producing low callus (Figs. 1, 9), sometimes planar (Fig. 7). Umbilicus opened (Fig. 4), protected on right side by middle region of inner lip (Figs. 1, 7, 9). Immature specimen bulimuliform (Figs. 11, 24).

Habitat: Caatinga and dry Atlantic Rainforest, $\sim 500 \mathrm{~h} \mathrm{high.}$
Distribution: Only know from type locality.

Measurements (in mm): Holotype MZSP 154048 (Figs. 1-6): 10.5 by 4.1; MZSP 154047 \# 1 (Figs. 7-8): 10.2 by 4.6; \#2: 11.3 by 4.0; \#3 (Figs. 11-12): 7.5 by 3.9; Paratype MZSP 153803 \#1 (Figs. 9-10): 11.0 by 4.1 .

Material examined: Types.

\section{Stapafurdius costiferus sp. nov. (Figs. 13-23, 27-29)}

http://zoobank.org/4AEDCA60-4A2A-4F04-9CC4-6517F1303B78

Types: Holotype MZSP 154046 (Figs. 13-18, 21). Paratypes MZSP 153882, 3 shells from type locality (Figs. 19-20, 22-23).

Type locality: BRAZIL. Bahia: Andaraí, Ubiraitá, $12^{\circ} 35^{\prime} 23^{\prime \prime} \mathrm{S}, 41^{\circ} 00^{\prime} 26^{\prime \prime} \mathrm{W}$ [Wesley Vailant col., iii.2021] (Fig. 30).

Etymology: The specific epithet means "bearing ribs" in Latin, an allusion to the shell axial sculpture.

Diagnosis: Shell rather cylindrical, sculpture strong axial cords.

\section{Description}

Shell: About $12 \mathrm{~mm}$, elongated, slightly turriform; width $\sim 30 \%$ of length. Spire angle initially $\sim 25^{\circ}$, becoming almost cylindrical in two last whorls, i.e., growth increasing relatively uniformly in first 3-4 whorls, gradually becoming same-sized in two last whorls, except for peristome slightly dislocated externally. Color pale beige, with relatively wide, sparse, brown spots, of apparent random distribution (Figs. 13-15, 22). Protoconch (Figs. 18, 23, 28, 29) of 2.5 whorls, width $1.1 \mathrm{~mm}$; whorls relatively rounded, suture deep; sculpture delicate net of spiral and axial lines, equally predominating, uniform, easily eroded (Fig. 18); $30 \%$ of shell width, $~ 5 \%$ of shell length; transition with teleoconch relatively clear, prosocline, $\sim 20^{\circ}$ in relation of longitudinal axis (Figs. 28, 29). Teleoconch of $\sim 5$ whorls, suture relatively shallow, but well-marked; transverse section rounded (Fig. 17); peristome dislocated externally to right, from slightly (Figs. 19-20) to well-dislocated (Figs. 13, 15). Sculpture uniform axial cords, 20 in penultimate whorl; each cord well-marked, from suture to suture (except for short region preceding superior suture) (Fig. 27); cords interspaces equivalent to double of cords width; interspaces with aligned minute dots parallel to cords (Figs. 21, 28); in last whorl sculpture similar to other regions, contouring inferior last whorl region, fading inside umbilicus (Figs. 13, 16, 20). Aperture antero-posteriorly elongated, width $\sim 40 \%$ of length (Figs. 13, 20); peristome slightly prosocline, $\sim 10 \%$ in relation to longitudinal axis (Fig. 14); outer lip straight in middle, curved in both ends; anterior edge rounded; inner lip relatively similar to outer lip, 
attached to last whorl only in its superior third, sometimes producing low callus (Figs. 20), sometimes planar (Fig. 13). Umbilicus opened (Fig. 16), protected on right side by middle region of inner lip (Figs. 13, 20). Immature specimen subuliniform (Figs. 22, 27).

Habitat: Caatinga and dry Atlantic Rainforest, $\sim 575 \mathrm{~h}$ high.

Distribution: Only know from type locality.

Material examined:Types.
Measurements (in $\mathbf{m m}$ ): Holotype MZSP 154046 (Figs. 13-18, 21): 12.0 by 3.6; Paratypes MZSP 153882 \#1 (Figs. 19-20): 11.1 by 3.5; \#3 (Figs. 22-23): 9.8 by $3.0 \mathrm{~mm}$.

\section{DISCUSSION}

There is almost no doubt that Stapafurdius gen. nov. is a new genus, as nothing similar exists in South America. The most similar genera are discussed below. The main problem is, however, to attribute a family to the new

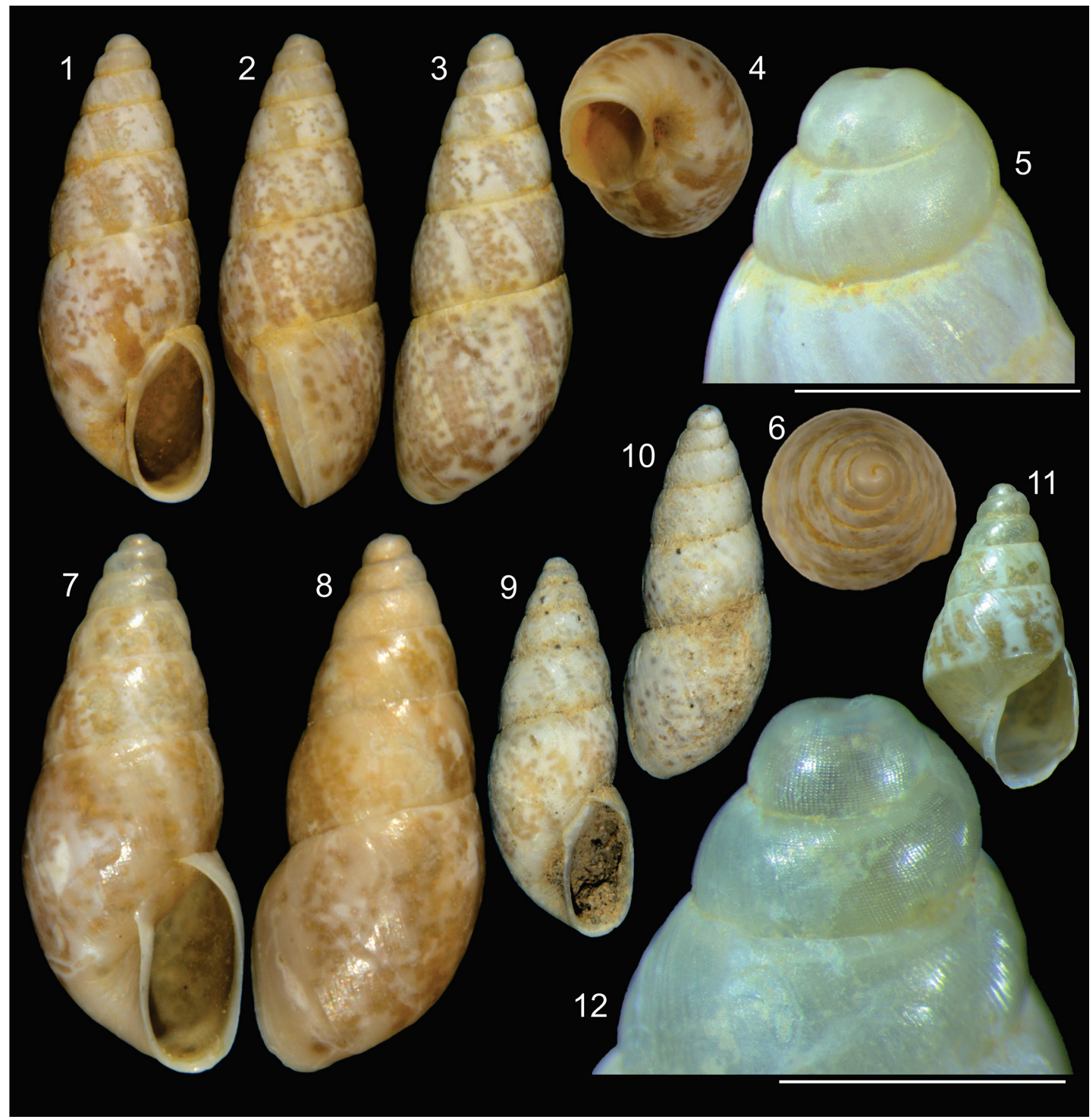

Figures 1-12. Stapafurdius glaber sp. nov., shell of types. (1-6) Holotype MZSP 154048 (L $10.5 \mathrm{~mm}$ ). (1) frontal view. (2) right view. (3) dorsal view. (4) inferior view. (5) protoconch and first teleoconch, profile, scale $=1 \mathrm{~mm}$. (6) apical view. (7-8) paratype MZSP 154047\#1 (L 10.2 mm), frontal and dorsal views. (9-10) paratype MZSP 153803\#1 (L $11.0 \mathrm{~mm}$ ): frontal and dorsal views. (11-12) paratype MZSP 154047\#3, immature shell (L $7.5 \mathrm{~mm})$, (11) frontal view. (12) detail of protoconch and first teleoconch whorl, profile, scale $=1 \mathrm{~mm}$. 
genus. Tentatively it has been considered Bulimulidae. However, this family has recently suffered radical changes, mostly based on molecular approaches (e.g., Breure et al., 2010; Breure \& Romero, 2012; Bouchet et al., 2017). However, these changes have not been accompanied by efforts to provide visible diagnostic features to the taxa, precluding the analyses of taxa lacking molecular known sequences. Those papers (and references therein), however, are good bases for showing how weak is the orthalicoidean systematics, that some of considered genera are clearly polyphyletic, and they need to be divided. The introduction of new genera appears inevitable. The general bulimuloid shape of Stapafurdius gen. nov., and the peristome lacking teeth are the main reasons for considering it a bulimulid. However, as reported below, some of the genera that need to be compared by their conchological similarity belong to other orthalicoidean families.

The last whorl of Stapafurdius gen. nov., having an umbilicus and antero-posteriorly elongated peristome, is similar to Anctus Martens, 1860 (Simone, 2006: 173), considered a bulimulid or orthalicid, but it differs by the elongated spire and outline, and pale protoconch, as Anctus has obese shell, with dark, not-sculptured protoconch. Elongated peristomes are also found in some species of Moricandia Pilsbry \& Vanatta, 1898 (Simone, 2006: 171-172), odontostomid, from which Stapafurdius

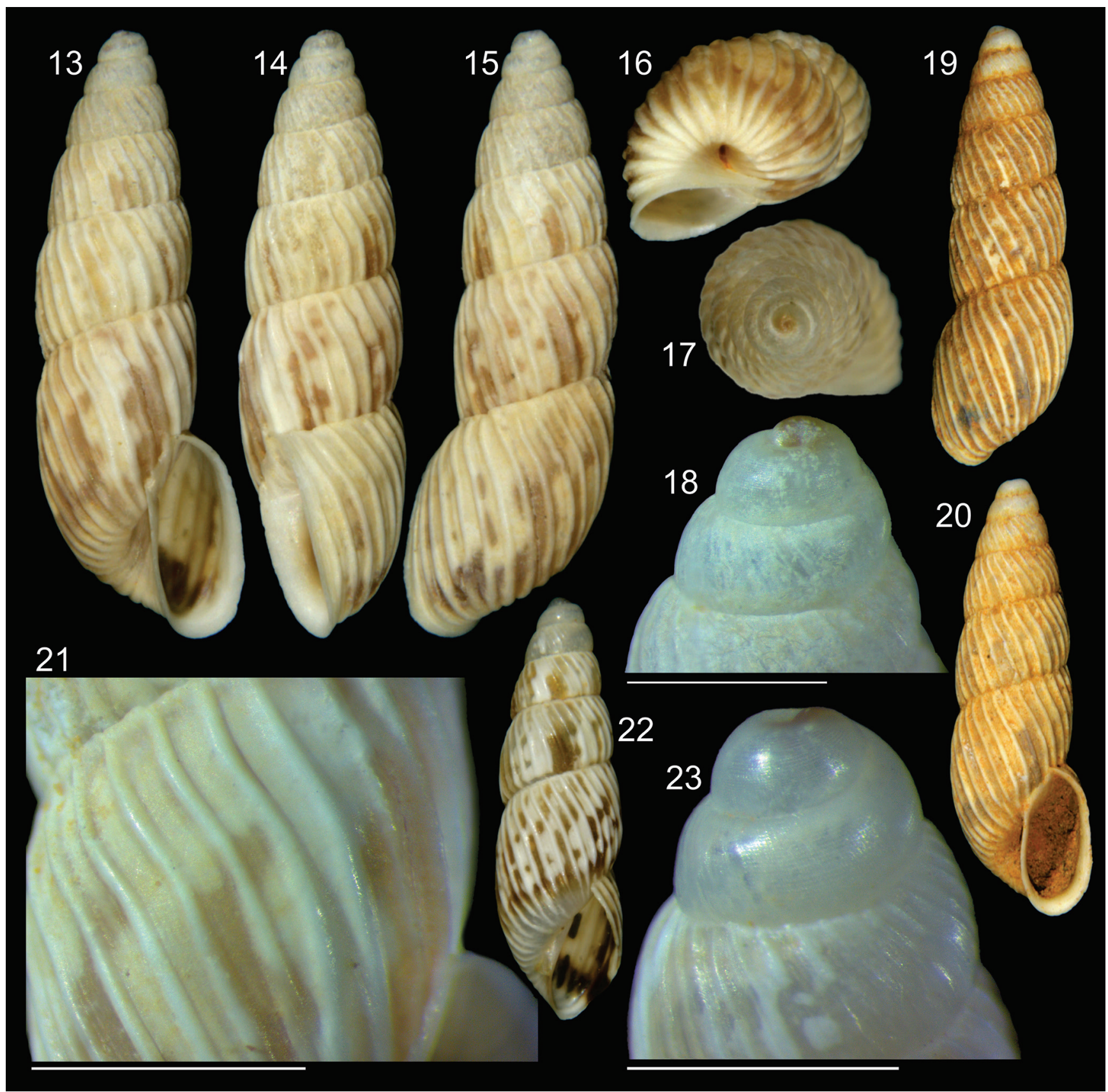

Figures 13-23. Stapafurdius costiferus sp. nov., shell of types. (13-17) Holotype MZSP 154046 (L $12.0 \mathrm{~mm}$ ). (13) frontal view. (14) right view. (15) dorsal view. (16) inferior-slightly left view. (17) apical view. (18) protoconch and first teleoconch, profile, scale = $1 \mathrm{~mm}$. (19-20) Paratype MZSP $153882 \# 1$ (L 11.1 mm): dorsal and frontal views. (21) holotype, detail of sculpture of penultimate whorl, scale $=1 \mathrm{~mm}$. (22-23) paratype MZSP $153882 \# 3$ (L 9.8 mm). (22) frontal view. (23) protoconch and first teleoconch, profile, scale $=1 \mathrm{~mm}$. 
gen. nov. differs in being much smaller, less elongated, and by the opened umbilicus; the elongated peristome of Moricandia actually is oblique, while that of Stapafurdius gen. nov. is longitudinal; the protoconch of Moricandia has a similar sculpture as Stapafurdius gen. nov., but Stapafurdius gen. nov. differs in having the sculpture still more delicate, and in having rounded whorls, while Moricandia has a blunt middle carina, keeping the apex rather umbilicated. The tall spire, the elongated peristome, the opened umbilicus, and the pigmentation also differ Stapafurdius gen. nov. from Bulimulus Leach, 1814, Protoglyptus Pilsbry, 1897, both bulimulid, and from Rhinus Martens, 1860, simpulopsid (Simone, 2006, and references therein; Breure \& Romero, 2012). Rhinus and Bulimulus also have reticulated protoconchs, however their sculpture is rougher and slightly more irregular. The odontostomid subgenus Ventania Parodiz, 1940, also has species with elongated outline, and peristome lacking teeth, however, the elongated peristome and the opened umbilicus differ Stapafurdius gen. nov. from it. From the odontostomid Clessinia Döring, 1875, Stapafurdius gen. nov. differs in having the elongated peristome, the opened umbilicus, lack of palatal tooth in the peristome, and by more delicate protoconch sculpture, as Clessinia has clear predominance of strong axial cords. From the odontostomid Spixia Pilsbry \& Vanatta, 1898, Stapafurdius gen. nov. differs by the elongated peristome (Spixia has a rounded one), in lacking peristome teeth (all Spixia have strong teeth in the aperture), by the cylindric anterior portion (Spixia has a continuous shell increment), and by the reticulated protoconch (Spixia has only strong axial cords as protoconch sculpture). From the odontostomid Bahiensis Jousseaume, 1877, Stapafurdius gen. nov. mainly differs by the external position of the peristome, dislocated because of the ample umbilicus, while Bahiensis has the peristome centrally positioned, practically lacking umbilicus; besides, Bahiensis has the peristome widely expanded, while Stapafurdius gen. nov. almost lack expansions; similarly, Stapafurdius gen. nov. has resem-

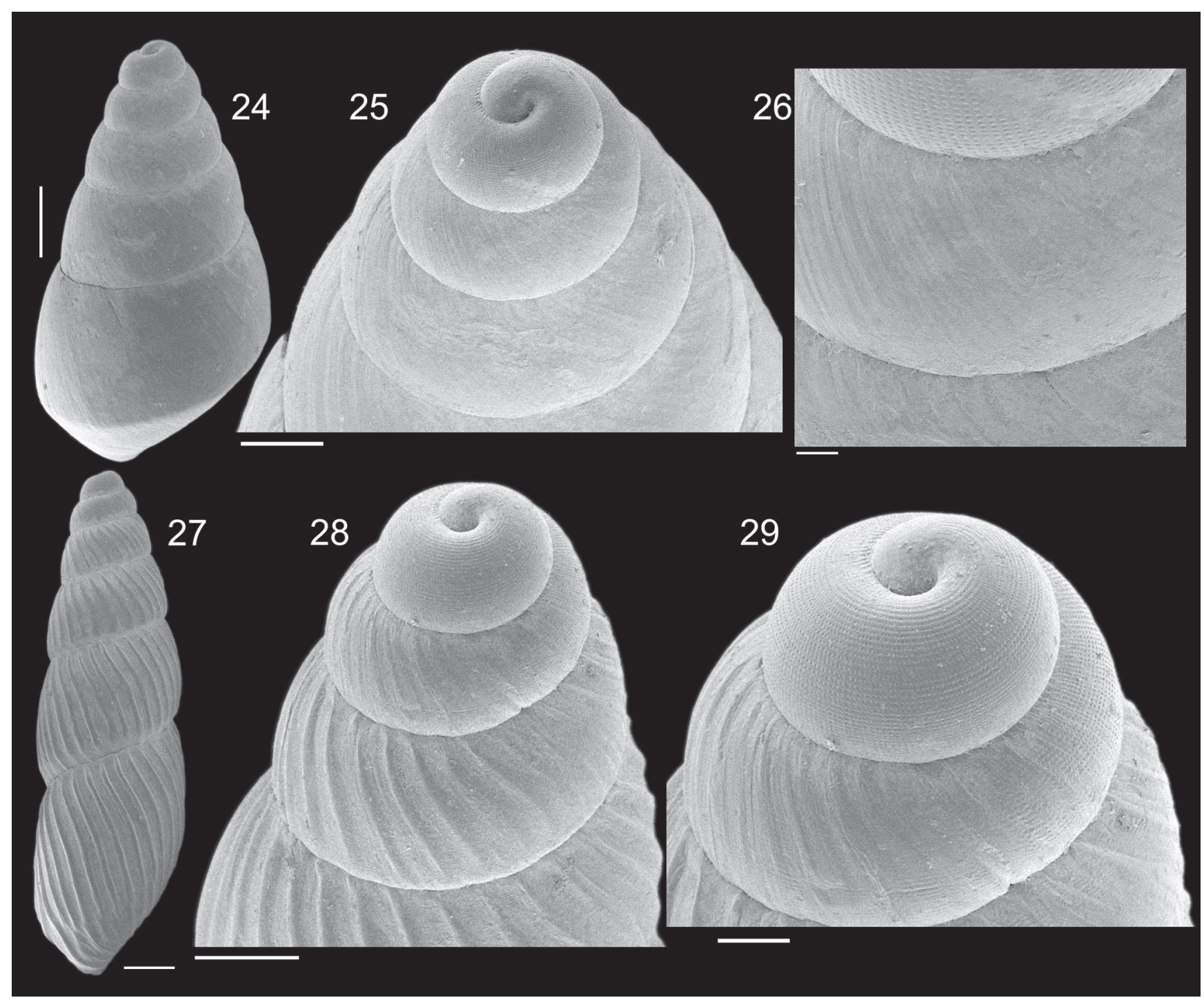

Figures 24-29. Stapafurdius gen. nov. young shell SEM images. (24) S. glaber sp. nov. paratype MZSP 154047, whole dorsal view, scale = $1 \mathrm{~mm}$. (25) same, detail of apical region, dorsal-slightly apical view, scale $=500 \mu \mathrm{m}$. (26) same, detail of transition protoconch-teleoconch, scale $=100 \mu \mathrm{m}$. (27) S. costiferus sp. nov. paratype MZSP 153882, whole dorsal view, scale $=1 \mathrm{~mm}$. (28) same, detail of apical region, dorsal-slightly apical view, scale $=500 \mu \mathrm{m}$. (29) same, detail of protoconch and first teleoconch whorl, scale $=200 \mu \mathrm{m}$. 


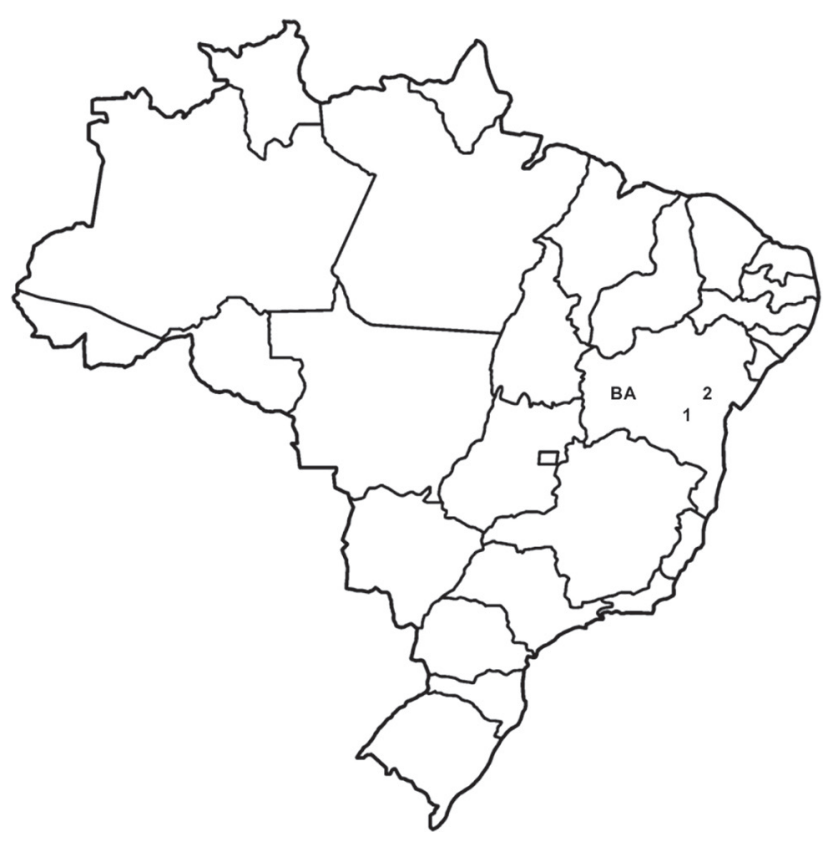

Figure 30. Map of Brazil with states outlined. Bahia indicated by "BA", with indication of places of occurrence of Stapafurdius glaber sp. nov. (1 = Ituaçu) and of $S$. costierus sp. nov. ( 2 = Ubiraitá).

blance of the protoconch sculpture of Bahiensis, despite being really more delicate; also, some Bahiensis have tooth-lacking peristome, but the peristome is always expanded, mainly anteriorly, which is not observed in Stapafurdius gen. nov. Two other bulimulid genera looks closer to Stapafurdius gen. nov.: Drymaeus Albers, 1850 and Bostryx Troschel, 1847. Stapafurdius gen. nov. differs from Drymaeus in having much smaller size (typical Drymaeus are $~ 30 \mathrm{~mm}$ ), elongated outline (while Drymaeus have a clear bulimuloid shape), and elongated peristome; the protoconch of Stapafurdius gen. nov. differs in being much smaller and by the delicate sculpture, the protoconch of Drymaeus also has reticulate sculpture, but more robust, with stronger axial and spiral lines; additionally, typical Drymaeus lack or have pressed umbilicus. Bostryx is a genus occurring in the Andean region and near the Pacific coast of South America (no Bostryx occurs in Brazil - Pilsbry, 1898; Simone, 2006), and has a wider range of shapes and protoconchs; some species also have elongated shape, and some are even slightly cylindric, however, their peristome are never elongated; their protoconchs vary from smooth to reticulated, however, even the reticulated forms do not have a so delicate sculpture like that of Stapafurdius gen. nov.; the elongated forms of Bostryx usually have deep suture, so much that some species have scalariform last whorl. No other orthalicoidean genus can be somehow confused with Stapafurdius gen. nov. Focusing the protoconch of Stapafurdius gen. nov., it looks the single genus with so delicate sculpture, constituted of squared aligned pits, instead of being composed of minute axial and spiral lines like the other orthalicoideans that possess reticulated protoconchs.

The elongated peristome, based on the experience in collecting Anctus, is related to the habit of the snail to dovetail it in narrow dry bushes, very common in
Northeast Brazilian region. The animal can, thus, hibernate during the dry season. The elongated peristome does not appear a defense mechanism, which more usually is the presence of teeth (Simone, 2018).

The protoconch of Stapafurdius gen. nov. is similar to most bulimulid and allied genera, in having the delicate net of spiral and axial lines equally predominating. The main exclusivity is the paucispiral condition (slightly more than 2 whorls) while most genera have more than 3 whorls.

Both Stapafurdius gen. nov. species easily differ from each other by the shell sculpture, as S. glaber sp. nov. is smooth (Figs. 1-3), while S. costiferus sp. nov. has strong axial sculpture (Figs. 13-15). Additionally, S. costiferus sp. nov. has slightly more elongated outline (width $\sim 30 \%$ of length, against $\sim 36 \%$ of S. glaber sp. nov.), and its protoconch is slightly longer, 2.5 whorls (against 2.2 of S. glaber), despite being slightly smaller $(1.1 \mathrm{~mm}$, against $1.2 \mathrm{~mm}$ of $S$. glaber sp. nov.).

The genus Stapafurfius gen. nov. so far appears to be endemic to the central Bahia dry region (Fig. 30). This present discovery joins several recent ones describing new species and even new genera (e.g., Simone, 2013, in press; Simone \& Oliveira, 2021; Simone \& Salvador, 2021), showing how weak is the knowledge on the Brazilian malacofauna. Possibly protective efforts must be implemented to preserve such species and environments. The proper description of the fauna is a first step.

\section{ACKNOWLEDGMENTS}

The samples studied were collected and donated by José Coltro-Jr. and his team of Femorale, for whom I am very grateful; additionally, he also commented some aspects of the taxonomy and of the paper. I also thank to two anonymous referees and the editor for comments, corrections and opinions that improved the paper. The collection was performed under IBAMA-ICMBio license 10560-1.

\section{REFERENCES}

Birckolz, C.J.; Salvador, R.B.; Cavallari, D.C. \& Simone L.R.L. 2016. Illustrated checklist of newly described (2006-2016) land and freshwater Gastropoda from Brazil. Archiv für Molluskenkunde, 145(2): 133-150.

Bouchet, P.; Rocroi, J.P.; Hausdorf, B.; Kaim, A.; Kano, Y.; Nützel, A.; Parkhaev, P.; Schrödl, M. \& Strong, E.E. 2017. Revised classification, nomenclator and typification of gastropod and monoplacophoran families. Malacologia, 61(1-2): 1-526.

Breure, A.S.H. \& Romero, P.E. 2012. Support and surprises: molecular phylogeny of the land snail superfamily Orthalicoidea using a threelocus gene analysis with a divergence time analysis and ancestral are reconstruction. Archiv für Molluskenkunde, 141(1): 1-20.

Breure, A.S.H.; Groenenberg, D.S.J. \& Schilthuizen, M. 2010. New insights in the phylogenetic relations within Orthalicoisea (Gastropoda, Stylommatophora) based on 285 sequence data. Basteria, 74(1-3): 25-31.

Parodiz, J.J. 1940. Ventania nuevo subgénero de Odontostomus. Notas del Museo de la Plata, Zoología, 5(42): 227-234. 
Pilsbry, H.A. 1897-1898. American Bulimulidae. In: Manual of conchology structural and systematic, second series Pulmonata. Philadelphia, Gwtj. Ser. 2, v. 11, p. 1-339, 51 pls.

Simone, L.R.L. 2006. Land and freshwater molluscs of Brazil. São Paulo, EGB, FAPESP. 390p.

Simone, L.R.L. 2013. Habeas, a new genus of Diplommatinidae from Central Bahia, Brazil (Caenogastropoda), with description of three new species. Journal of Conchology, 41(4): 519-525.

Simone, L.R.L. 2018. Physical defense strategies of South American land snails. Malacopedia, 1(2): 3-11. http://www.moluscos.org/ trabalhos/Malacopedia/01-02\%20Simone\%202018\%20Physical\%20 strategies\%20of\%20defense.pdf.
Simone, L.R.L. in press. Review of the genus Habeas from Brazil, with description of four new species in which anatomical features revealed Urocoptidae affinity (Eupulmonata, Stylommatophora. Malacologia.

Simone, L.R.L. \& Oliveira, G.V. 2021. A new species of the micro snail genus Heleobia (Caenogastropoda, Cochliopidae) from Bahia, Brazil. Papéis Avulsos de Zoologia, 61: e20216143. D0I

Simone, L.R.L. \& Salvador, R.B. 2021 A new species of Spiripockia from eastern Brazil and reassignment to Cochliopidae (Gastropoda: Truncatelloidea). Journal of Natural History, 54(47-48): 3121-3130. D0I 